\title{
PoliCIES AND PRACTICES GOVERNING DISABILITY IN MALAYSIA'S HIGHER EDUCATION: A COMPARISON WITH ENGLAND AND AUSTRALIA
}

\author{
Clarene Tan ${ }^{a}$ \\ Melissa Ng Lee Yen Abdullah \\ Munir Shuib \\ Universiti Sains Malaysia
}

\begin{abstract}
Throughout the last decade in Malaysia, participation of students with disabilities in higher education has seen minimal growth. This paper investigates the policies and practices regulating disability in Malaysia's higher education. Three aspects - legislation, funding, and governance - are analysed. To reveal the gaps in policy and practice, comparison is carried out with the cases of England and Australia. The research involved examining government documents such as disability acts, action plans, and research and statistics reports, combined with interviewing university administrators. It was found that Malaysian legislation requires more supporting details and that disability funding for universities should be considered. For governance, systematic legislation review and specific university monitoring are recommended. Establishing an independent national entity to conciliate grievances is proposed to address the inadequate redress mechanism available for students with disabilities. Overall, the government and universities could ensure that disability information is available in the public domain, especially online. Such practice would enhance disability awareness and knowledge for all. Although this paper mainly takes on the perspective of a developing nation, it attains an international orientation as it also depicts the workings of the developed world in governing disability in higher education.
\end{abstract}

Keywords: higher education participation, student with disabilities, legislation, funding, governance, review, monitoring, redress, complaints, United Nations Convention on the Rights of Persons with Disabilities (CRPD)

\section{Introduction}

People with disabilities are among the most overlooked and neglected in the world (World Health Organization, 2013). In his study, Kamarulzaman (2007) opined that among the underserved factions in Malaysia, people with disabilities are indeed the nation's most vulnerable cohort. They are defined to be those with "long term physical, mental, intellectual or sensory impairments" (Persons with Disabilities Act [PwDA], 2008, pg. 9). One of the main factors that perpetuate people with disabilities in social exclusion and poverty is their inaccessibility to education, specifically, higher education. Especially in Asia, a higher education qualification is a prerequisite for most employment.

The Organization for Economic Co-operation and Development (OECD, 2011) reported that access of students with disabilities in higher education - albeit improving - is still a major concern. The enrolment numbers of students with disabilities at Malaysian public universities reflect as much (Table 1). Student enrolment in the public sector increased by over 30,000 students in the five-year period of 2011 to 2015 . However, no similar magnitude of upward trend was observed in the enrolment of students with disabilities at these institutions. Their enrolment rose by just a little

a Correspondence can be directed to: clarene12@gmail.com 
over 700 students for the same time period; their percentage of total enrolment increased by barely $0.15 \%$. Hence, despite the constant discourse on higher education access and equity in Malaysia, it seems that the participation of students with disabilities has scarcely improved.

Table 1. Enrolment at Malaysian Public Higher Education Institutions, 2011-2015

\begin{tabular}{l||ccccc}
\hline \multirow{2}{*}{ Enrolment } & \multicolumn{5}{c}{ Year } \\
& 2011 & 2012 & 2013 & 2014 & 2015 \\
\hline \hline $\begin{array}{l}\text { Enrolment of students with } \\
\text { disabilities }\end{array}$ & 1,221 & 1,372 & 1,572 & 1,742 & 1,930 \\
\hline Total enrolment & 508,256 & 521,793 & 560,359 & 563,186 & 540,638 \\
\hline $\begin{array}{l}\text { \% of enrolment of students } \\
\text { with disabilities }\end{array}$ & $0.24 \%$ & $0.26 \%$ & $0.28 \%$ & $0.31 \%$ & $0.36 \%$ \\
\hline
\end{tabular}

Source: Ministry of Higher Education (MoHE; 2013; 2015b; 2016b)

The Social Model of Disability underlines that disability issues do not stem from the shortcomings of those with disabilities but from disabling environments and cultures (Barnes, 2007). One of the dominant factors that steers a societal environment and culture is the policies and practices that regulates the society's constitution. This paper aims to examine the policies and practices that regulate disability in Malaysia's higher education. Comparison is made with that of two other countries: England and Australia. Discussion is centred on three key aspects of disability policy and practice: legislation, funding, and governance.

\section{Approach}

The United Nations Educational, Scientific and Cultural Organization's (UNESCO) Education 2030 Incheon Declaration and Framework for Action is the implementation plan for the 4th Sustainable Development Goal (SDG4) of quality education. The 5th target of SDG4 addresses gender equality and inclusion, which includes matters concerning persons with disabilities (United Nations, 2017b). In achieving that 5th target, the Framework sets out to, among others, ensure that education policy and budgeting protect against any discrimination (UNESCO, 2016). Disability legislation and policies regulating cost allocation and reasonable accommodation provision are important elements in tertiary education access for students with disabilities (Committee on the Rights of Persons with Disabilities, 2009, 2016).

UNESCO's Framework and reporting for the United Nations Convention on the Rights of Persons with Disabilities (CRPD) essentially require member countries to monitor, follow up, and review their education legislation, policies, and systems. According to the legal framework for protecting human rights by UNESCO (2014), besides common indicators such as 'laws', 'available remedies' in the event of rights violation is also a significant factor. Hence, legislation, funding, and governance form the core of this paper on policy and practice governing disability in higher education. Governance covers review, monitoring, and redress.

Due to the British colonisation of Australia and Malaysia, the legal system of both countries is essentially derived from English laws (Australian Law Reform Commission, 2017; Castles, 1963; Shaikh Mohamed \& Supramaniam, 2016). The legal framework between the three countries, therefore, holds many parallels (and relatable distinctions). Also, as England and Australia are developed 
nations, a study on their disability regulation in higher education is apt in drawing feasible milestones for Malaysia (a developing country). To this end, in this paper, the policies and practices for each country are presented on the three aspects mentioned. ${ }^{1}$ Nevertheless, authors in the field have highlighted issues on postcolonial conditions and adopting disability practices of previous colonial powers (Grech, 2011; Meekosha, 2011). Thus, analyses are conducted on the Malaysian policies and practices in comparison with those of the other two countries to elicit recommendations suitable to Malaysia's context and aspirations.

The bulk of the research was carried out through analysing official secondary data from the governments of Malaysia, England, and Australia. Acts, policy documents, action plans, research reports, and statistics were among the many items examined. Primary data were collected from interviews with four administrators of Malaysian and Australian universities towards the end of 2016. The next section provides an overview of the current context of disability in Malaysia's higher education. This is followed by the three-aspect analyses, including the respective implications and recommendations for Malaysia. Challenges of the study and possible future research conclude the paper.

\section{Disability Context in Malaysia's Higher Education}

The legislation that protects people with disabilities in Malaysia is the Persons with Disabilities Act (PwDA; 2008). People with disabilities are mainly under the purview of the Department of Social Welfare (DSW); Ministry of Women, Family and Community Development (MWFCD; DSW, 2017b). The National Council for Persons with Disabilities (NCPD), established under the PwDA, is tasked with implementing the provisions of the said Act (PwDA, 2008). To this end, the Council, among others, oversees and carries out the nation's formal policy for persons with disabilities and its action plan.

Complete participation of people with disabilities in society forms the core of Malaysia's National Policy for Persons with Disabilities 2007 (MWFCD, 2007). The action plan - currently the People with Disabilities Action Plan 2016-2022 - is envisioned to execute the said policies. Malaysia agreed to take on the Incheon Strategy (United Nations Economic and Social Commission for Asia and the Pacific, 2012). As such, the core strategies of the 2016-2022 Action Plan are in alignment with Incheon Strategy's 10 disability development goals. The $3^{\text {rd }}$ core strategy is centred on improving access at all education levels (MWFCD, 2016).

Special education in Malaysia receives insufficient attention in general, and in research, there is a dearth of related literature (Lee \& Low, 2014). The issue is heightened the higher education level. Though the Malaysia Education Blueprint 2013-2025 devotes considerable focus to special education at the primary and secondary level, the Higher Education Blueprint 2015-2025 barely touches disability (Ministry of Education [MoE], 2013, 2015). Lee and Low (2014) also underlined three pertinent inadequacies rampant among developing nations: 1) facilities and training, 2) funding framework, and 3) viable legislation. Thus, a study on the disability policies and practices in Malaysian higher education is most appropriate.

\section{Legislation}

In Britain, the Equality Act (2010) protects, among others, students with disabilities against discrimination, harassment, and victimisation by higher education institutions. Student exclusion or denial of opportunities due to any such conduct is unlawful. Institutions have a duty to make reasonable adjustments to accommodate their students with disabilities. These adjustments are to be anticipatory and ongoing, and consist three aspects: 1) provision, criterion, and practice; 2) physical feature; and 3) auxiliary aid and service (Equality and Human Rights Commission [EHRC], 
2014a). Public universities have to ensure compliance with the Public Sector Equality Duty - both general and specific - extended by the Equality Act (2010).

As for Australia, Section 22 of the Disability Discrimination Act (DDA, 1992) makes it unlawful for universities to discriminate against students with disabilities in regards to admission, benefits, and course provision; Section 37 prohibits the harassment of such students. To underline the requirements of education institutions, the Disability Standards for Education (DSE, 2005) was established. The Standards mandates that students with disabilities be provided education opportunities on the same basis as those without disabilities. To this end, universities are to provide reasonable adjustments (DSE, 2005). As Australia is a federation, each state has its own jurisdiction and laws (e.g., the South Australia's Equal Opportunity Act, 1984). The stipulations of the DDA (1992) and the DSE (2005) operate within the pertinent state-based legislations.

For the case of Malaysia, as mentioned, the PwDA (2008) provides for the protection of people with disabilities. Exclusion of, among others, higher education students with disabilities by government and private education providers is prohibited. Reasonable accommodation is to be provided to meet their needs at universities. Table 2 summarises the respective legislations governing Britain, Australia, and Malaysia as well as the status of each country's international participation with the United Nations CRPD and the Convention's Optional Protocol (United Nations, 2017a, 2017c). The significance of such participation will be addressed in the Governance section.

Table 2. Legislation and International Participation of Britain, Australia, and Malaysia

\begin{tabular}{|l|l|l|l|}
\hline & Britain & Australia & Malaysia \\
\hline Act & Equality Act 2010 & $\begin{array}{l}\text { Disability } \\
\text { Discrimination Act } \\
1992 \\
\text { *supporting legislation: } \\
\text { Disability Standards for } \\
\text { Education 2005 }\end{array}$ & $\begin{array}{l}\text { Persons with } \\
\text { Disabilities Act 2008 }\end{array}$ \\
\hline $\begin{array}{l}\text { United Nations } \\
\text { Convention on the } \\
\text { Rights of Persons with } \\
\text { Disabilities }\end{array}$ & $\begin{array}{l}\text { Signatory (under the } \\
\text { United Kingdom) }\end{array}$ & Signatory & Signatory \\
\hline $\begin{array}{l}\text { Convention's Optional } \\
\text { Protocol }\end{array}$ & $\begin{array}{l}\text { Signatory (under the } \\
\text { United Kingdom) }\end{array}$ & Signatory & Nonsignatory \\
\hline
\end{tabular}

It is clear that all three nations do, indeed, have disability laws. The defining distinction is in the manner and amount of legislation support and guidance. Besides their main disability acts, the British and Australian governments supply ample supporting documents and information that provide universities with concrete elaborations, interpretations, and examples. Some documents are easy-to-read guides while others, legally enforceable. For example, in Britain, though the Technical Guidance on Further and Higher Education is nonstatutory in nature, it may be employed as evidence in court and tribunals (EHRC, 2014a). What Equality Law means for you as an Education Provider - Further and Higher Education (EHRC, 2014b), on the other hand, is among the many practical guides catered for the layman.

Specific supporting laws are stronger in Australia. The DSE (2005) is subordinate legislation under the DDA thus, legally enforceable; its stipulations are binding for universities. In addition, there is the Guidance Notes that further clarifies the 2005 Standards. As for easy-to-read guides, the Australian Government has provided substantial material such as factsheets, websites, and 
even systematic resource guides (Department of Education and Training [DET], 2016a; University of Canberra, 2014).

Malaysian legislation, on the other hand, does not receive any supporting guidance. The DSW (2017a) does provide the list of facilities and privileges extended by the different government ministries, including the Ministry of Higher Education (MoHE), to people with disabilities. This document, however, does not explain the requirements of the institutions or aid students and others in their expectations. The PwDA (2008) provides broad stipulations to include students with disabilities and extend reasonable accommodation but no specifics on what those entail. Details are crucial for effective implementation. Giving proper support limits subjective interpretation; it not only protects the student with disabilities but also all parties involved.

The understanding and specifics of concepts such as disproportionate and undue burden in disability legislation are of notable importance (Committee on the Rights of Persons with Disabilities, 2009). The laws of all three countries provide for instances where it is not unlawful for institutions to not make adjustments or accommodation. The difference is while Britain and Australia have explicit legislation addressing this issue, Malaysia's PwDA has the implications embedded in its definition of reasonable adjustment (PWDA 2008, p. 9). The concepts of proportionate means of achieving a legitimate aim in Britain and of unjustifiable hardship in Australia receive considerable focus in both the respective Acts and their guidance material. In Malaysia, the issue remains ambiguous as there is no further information found in the PwDA and no supporting documents providing clarification.

\section{Implications and Recommendations for Malaysia}

As certain concepts are underdeveloped and official supporting details, limited, Malaysian disability laws are opened to an institution's own discretion and interpretation. Such settings perpetuate the culture where "society will give as and when it chooses" (Sinnasamy, 2010). People with disabilities in the county are still mostly seen as cases of charity and welfare (United Nations Children's Fund [UNICEF] Malaysia's, 2014).

Hence, instead of providing the necessary accommodation, the university's resource availability determines if a student with disabilities is admitted (UNICEF Malaysia, 2014). As most Malaysian universities have no disability policy or statement, incorporation of any practice is piecemeal at best; laws are subjectively embedded into the different constitutions governing the institution. The authors examined the websites of 15 public universities and found that merely four had any disability information. Students with disabilities are still mostly an overlooked population in Malaysian higher education.

In view of the above, more substantial guidance from the NCPD is called for. Supporting legally-enforceable legislation and easy-to-read guidelines to the PwDA are imperative. Although examples from the developed nations can be used as a genesis, ultimately, the guidelines must be drawn from the Malaysian context of disability. Specific to higher education, the elements that constitute reasonable accommodation at the university should be outlined and readily found on the website of the DSW and the MoHE. Granted that Perren. Roberts, Stafford, and Hirsch (2012b) is a British review, this study revealed that the government website is the most common of sources in pertinent information seeking.

As for the universities, they are encouraged to have at least a disability element visible on their webpage such as a tab leading to information on disability facilities. Beyond that, institutions should also have a disability policy, one that students can easily access from the university's website. Although there is a risk of the policy becoming just another document invoking no real action (a concern brought up by respondent during interview in a Malaysian university), policy establishment is still highly recommended if for nothing else than to be the ignition of disability awareness. Perren et al. (2012a, 2012b) associated good organisation practice and equality awareness with having a written policy. 


\section{Funding}

This section examines the funding practice of the government specific towards the higher education student with disabilities and towards the university specifically to cover disability costs. Undoubtedly, other funding options such as university loans for the student and business investments for the institution are available. This study, however, focuses on government provision. Funding level analysis is beyond the scope of the paper.

In England, the main government funding scheme for higher education students with disabilities is the Disabled Students' Allowance (DSA; Government of the United Kingdom [GUK], 2017a). Those funded by the National Health Service (NHS) Student Bursaries (e.g., students studying to be doctors and dentists) are eligible to a similar disability allowance but under their bursary (GUK, 2017b). Starting for years 2017-18, to recruit and support students with disabilities, publicly funded universities receive the Disabled Students' Premium from the Higher Education Funding Council for England (HEFCE'; HEFCE, 2017). The premium follows an institutional weighting method (with a floor minimum in allocation). The amount is calculated according to the proportion of students who receive the DSA and who self-declare a disability at a weightage of 2 and 1 respectively.

As for Australia, higher education students with disabilities in receipt of certain financial support from the Department of Human Services (DHS) are entitled to the extra Pensioner Education Supplement, a small fortnightly payment designed to help with study costs (DHS, 2017). Universities, on the other hand, receive disability funding primarily through the Higher Education Disability Support Program (DSP, Table 3) from the Department of Education and Training (DET).

Table 3. Components of the Higher Education Disability Support Program in Australia

\begin{tabular}{|l|l|l|}
\hline No. & Component & Description \\
\hline (1) & $\begin{array}{l}\text { Additional Support } \\
\text { for Students with } \\
\text { Disabilities (ASSD) }\end{array}$ & $\begin{array}{l}\text { provided to universities to aid them in availing } \\
\text { equipment and education support to students with } \\
\text { disabilities } \\
\text { this component reimburses the institution a } \\
\text { portion of the said disability expenditure (50\%-60\% } \\
\text { of education support expenditure and 100\% of } \\
\text { equipment cost) }\end{array}$ \\
\hline (2) & $\begin{array}{l}\text { Australian Disability } \\
\text { Clearinghouse on } \\
\text { Education and Training } \\
\text { (ADCET) }\end{array}$ & $\begin{array}{l}\text { provided to the university hosting the ADCET } \\
\text { website - currently, the University of Tasmania } \\
\text { the ADCET website provides information and } \\
\text { resources on higher education inclusive practices }\end{array}$ \\
\hline (3) & $\begin{array}{l}\text { Performance-Based } \\
\text { Disability Support } \\
\text { Funding }\end{array}$ & $\begin{array}{l}\text { provided to universities in spurring them to carry out } \\
\text { strategies in attracting and providing for students } \\
\text { with disabilities }\end{array}$ \\
\hline
\end{tabular}

Source: Commonwealth of Australia (2012); DET (2015a)

In Malaysia, higher education students with disabilities may receive a monthly pocket stipend and a set course fee subsidy from the Malaysian government (DSW, 2017a). To champion equity and lifelong learning, Open University Malaysia offers a 75\% fee waiver to those with disabilities and senior citizens. As for government funding to the universities, there is no allocation provided (MoE, personal communication). Any accommodation or scholarships extended to students with disabilities is financed on the institution's own initiative. Table 4 depicts the respective government provision practice for the three nations in regards to disability in higher education. 
Table 4. Government Funding Provision Practice for Disability in Higher Education in England, Australia, and Malaysia

\begin{tabular}{|l|c|c|}
\hline & Government to student with disabilities & Government to university \\
\hline England & $\checkmark$ & $\checkmark$ \\
\hline Australia & $\checkmark$ & $\checkmark$ \\
\hline Malaysia & $\checkmark$ & $\times$ \\
\hline
\end{tabular}

Institutions in England and Australia receive government disability financial provision, which holds base-level and performance-based elements. Malaysian universities, on the other hand, receive no government disability allocation. The Malaysian government, however, does fund special disability institutions, some of which extend education, vocational and industrial training, and job placement services to people with disabilities (DSW, 2017a). Electric, electronics, information technology, fashion design, and batik production are among the many training areas offered (Singh, 2014).

\section{Implications and Recommendations for Malaysia}

The disability allocation by the English and Australian governments to their universities indicates that provision for students with disabilities by regular higher education institutions is an important agenda for them. Undeniably, the Malaysian government does provide for the education and welfare of students with disabilities. Nonetheless, missing in its funding practice is the cue to its universities on the significance of the disability cause in the nation's higher education. In Australia, DET (2015a) found that the DSP aided in increasing the university's awareness on disability support and inclusive practices.

Although the Malaysian institutions can subscribe to other sources of funding, provision from the government is essential in disability accommodation (see analysis of the Centre for Disability Studies and School of Sociology and Social Policy, 2009, on the importance of HEFCE monies in this regard). Hence, the Malaysian government should consider providing a disability allocation in their annual funding to the universities. Due to the current low volume of these students, a feasible start could be a capped reimbursement procedure. Institutions could perhaps claim, up to a ceiling level, for their disability expenses of the previous year (a practice adapted from part of the Australian mechanism).

When the volume increases in future, a small allocation (to be revised after a set duration) could be provided to individual universities based on each institution's number of students with disabilities. The essential factor at this stage is not so much the level of funding but the existence of the fund itself; it underlines the disability priority for Malaysian institutions. Nonetheless, establishing provision, usage, reporting, and publication policies for the Ministry and the university must accompany the disability allocation.

As for the universities, the shrinking budgets provided by the government have caused major cuts in funds for every aspect of their operations. Allotting even a small sum (from the current budget) for disability would be a challenge. Thus, universities could perhaps focus on forming good relations with notable donors in Malaysia and abroad to draw in endowments, gifts, and collaborations specifically to support disability.

For example, the University of South Australia (UNISA) receives funds from benevolent private organisations to form grants that are provided to students with disabilities (interview respondent, Australian university). It is therefore recommended that every Malaysian university have a disability funding strategy planned out and put into place. Incidentally, the Malaysian government could also form partnerships with national and international organisations for disability funding (UNESCO, 2017a). 


\section{Governance}

Here, governance of disability policies and practices in higher education is examined in terms of review, monitoring (top-down mechanism), and redress (bottom-up mechanism). Review and monitoring in this paper refers to official government-initiated efforts. While review covers evaluating legislation and its effectiveness, monitoring refers to overseeing the progress of institutions in their disability policy implementation.

In England, various government bodies carry out reviews on the nation's disability policies. One prominent review was the survey ending January 2012 by the Government Equalities Office on the impact of the Equality Act on the workplace (Perren et al., 2012a, 2012b; Perren, Roberts, Stafford, Hirsch, \& Padley, 2012). More recently, the House of Lords (2016) examined the impact of the Act on people with disabilities. Periodically though, the Equality and Human Rights Commission (EHRC), being the regulator of the Equality Act (2010) and the Public Sector Equality Duty (EHRC, 2016, 2017b), produces statutory reviews on the progress of equality and human rights (higher education included; EHRC, 2015, 2017a). Specific to higher education, the Equality in Higher Education: Statistical Report is prepared annually by the Equality Challenge Unit (ECU), highlighting areas for action in improving inclusiveness (e.g., ECU, 2014, 2015, 2016).

As for monitoring, the following are examples of the public entities that oversee disability in higher education in England. The Higher Education Statistics Agency (HESA) monitors and publishes the figures of students with disabilities in the United Kingdom annually (HESA, 2017). Besides that, assessments on the compliance progress of public bodies, which include universities, have been carried out by the EHRC (EHRC, 2012, 2013). HEFCE, on the other hand, regulates the universities through two modes (HEFCE, 2012): 1) visiting them and discussing related matters and 2) requiring the individual universities to submit the yearly monitoring statement, which contains a query into the equality progress of the institution.

As for redress in England, should discrimination, harassment, or victimisation ensue at a university, students with disabilities can take action against the organisation (Chapter 2 of Part 9 [Enforcement] of the Equality Act, 2010). The student should first try to settle the issue informally with the institution (Disability Rights UK, 2017). Only after employing all internal university avenues should students turn to external options: the Office of the Independent Adjudicator (OIA) and/or the county court (EHRC, 2014c).

The OIA is an independent organisation that reviews student grievances against higher education institutions (OIA, 2017a). As for international recourse, because the United Kingdom is a member of the CRPD's Optional Protocol ${ }^{3}$ (as indicated in Table 2), English students can lodge a complaint with the Committee on the Rights of Persons with Disabilities (Office of the United Nations High Commissioner for Human Rights [OHCHR], 2017b). Nevertheless, one should first undergo the country's internal procedures (Figure 1).

Figure 1. England's Redress Mechanism for Higher Education Students with Disabilities

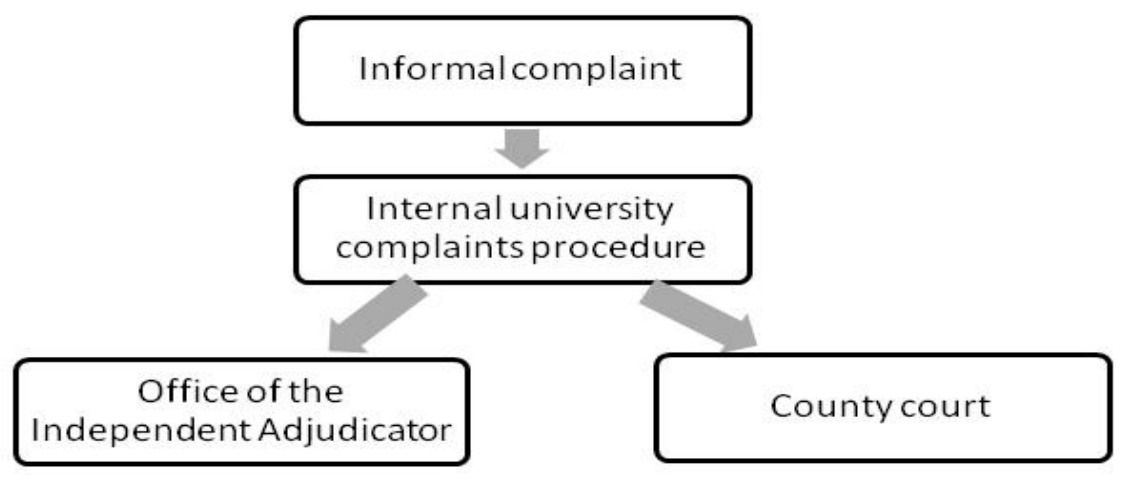


In Australia, there is periodic evaluation and review of disability legislation and strategy. For example, progress of the National Disability Strategy 2010-2020 is tracked and reported biennially (Commonwealth of Australia, 2011; see Department of Social Services, 2015, for the first progress report). Specific to higher education though is the review of the DSE (2005) every five years mandated by the Standards itself (see Urbis, 2015, for the final report of the latest review). Besides the above, the National Centre for Student Equity in Higher Education (NCSEHE), funded by the DET, undertakes equity-related research (NCSEHE, 2017b) thus, produces relevant statistics and reports (Koshy, 2016; NCSEHE, 2017a).

For monitoring, the DET does collect equity performance statistics, which include disability data, from the universities such as participation and success rates (DET, 2014, 2015b, 2016b). This practice, however, is mostly for budgeting purposes (interview respondent, Australian university). Agencies such as the Tertiary Education Quality and Standards Agency (TEQSA) are also more centred on overseeing the institution's standard and quality assurance. There is no actual mechanism in place to monitor the implementation of disability legislation, especially in relation to reasonable adjustment provision. Any such monitoring is entrusted to the universities themselves (interview respondent, Australian university). Redress mostly comes from student complaints and grievances.

Similar to England's redress practice, in Australia, external avenues are available to the student with disabilities only after internal university procedures have been exhausted (Figure 2). Students will then have to decide between conciliation using either their own state's mechanism or that of the Commonwealth (interview respondent, Australian university). This stage does not yet involve any court or legal proceedings. Opting for the Commonwealth route, students may bring their complaints to the Australian Human Rights Commission (AHRC Act, 1986).

The AHRC will then carry out an inquiry into the case that will result in either conciliation for all parties or complaint termination (DSE, 2005). Should termination ensue, students may then apply to the Federal Court or the Federal Circuit Court. Either court can make a finding and reach a verdict in which the student and the respondents to the case must respectively accept and comply with. For international aid, students may bring their grievances to the Committee on the Rights of Persons with Disabilities (after utilising the country's internal mechanism) as Australia is a member of the CRPD's Optional Protocol (refer to Table 2).

Figure 2. Australia's Redress Mechanism for Higher Education Students with Disabilities

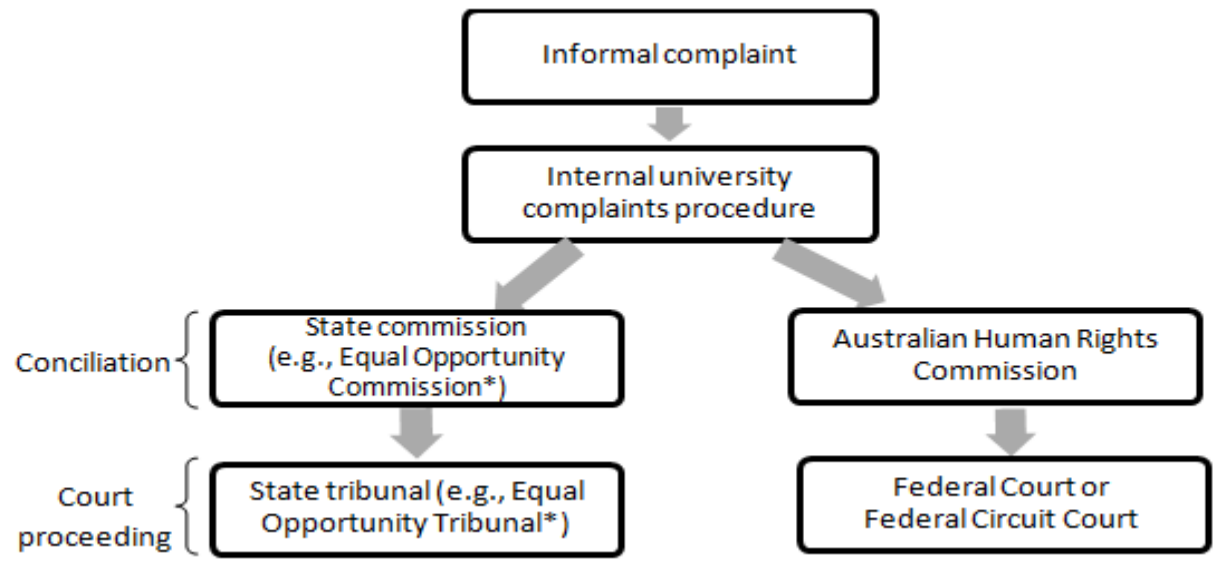

Note: *The Equal Opportunity Commission and the Equal Opportunity Tribunal are specific to state of South Australia (Equal Opportunity Commission, 2013). Other states have their own commission and tribunal. 
As for the Malaysian case, currently, no disability legislation reviews are found in the public domain. UNICEF Malaysia (2014) voiced that there was no progress evaluation of the first National Action Plan for Persons with Disabilities (2008-2012). For monitoring, Section 17 of the PwDA (2008) stipulates that the NCPD may require complete progress reports from public bodies on their implementation efforts in subscription to the Act. Nevertheless, the extent to which this section is carried out is not verifiable because the reports are not publicly available. In higher education, the MoHE does annually collect statistics of students and graduates with disabilities from higher education institutions (MoHE, 2016a, 2016b). Certain enrolment, graduate, and employment figures are published.

In terms of bottom-up enforcement, there is no legal complaints system or procedure invoked by the PwDA (2008) or any supporting document. In addition, Malaysia is not a member of CRPD's Optional Protocol (refer to Table 2). International avenue for grievances is, therefore, not available. Hence, the only accessible redress for students with disabilities in Malaysia would be the university's grievance procedure available for all individual complaints. Table 5 summarises the governance aspect for the three countries.

Table 5. Governance of Disability in Higher Education in England, Australia, and Malaysia

\begin{tabular}{|l|c|c|c|}
\hline & Review & Monitoring & $\begin{array}{c}\text { Redress Mechanism (provided by } \\
\text { legislation) }\end{array}$ \\
\hline England & $\checkmark$ & $\checkmark$ & $\checkmark$ \\
\hline Australia & $\checkmark$ & $\checkmark$ (partially*) & $\checkmark$ \\
\hline Malaysia & Undetermined & $\checkmark$ (partially*) & $\times$ \\
\hline
\end{tabular}

Note: * partially because there is monitoring of disability statistics (e.g., enrolment \& graduate numbers) but no monitoring of policy implementation and progress at universities

For review and monitoring, one distinction between the advanced nations and Malaysia is the availability of online reports. Most reports are readily accessible at the relevant government websites for England and Australia; such is not the case for Malaysia. In terms of redress, for England and Australia, there is a clear path from internal university to national and international routes. Both countries have judicial and quasi-judicial mechanisms in place (the Committee on the Rights of Persons with Disabilities is an international quasi-judicial body). Malaysia, on the other hand, provides no external university avenues (confirmed by respondent during interview, Malaysian university). Similar to Malaysia, Australia has instated legislation protecting the government against civil action (Section 126 of the DDA and Section 41 of the PwDA). However, Australian laws have gone on to preserve court rights for people with disabilities.

\section{Implications and Recommendations for Malaysia}

Singh (2014) underlined the issue of inadequate implementation by the authorities with regards to disability in Malaysia. The above analysis provides support for such a claim. However, the absence of evident review and certain monitoring factors, along with crucial redress elements, indicates a lack of commitment to enforcement by not only the government but the legislation itself. Lee and Low (2014) expressed that Malaysia's legislation hardly invokes compliance of organisations.

It must be noted though that the yearly tracer study prepared by the MoHE does devote an entire chapter to the facts and figures of graduates with disabilities (MoE, 2014; MoHE, 2015a, 2016a). Thus, disability in higher education does receive some monitoring priority. As for the matter 
of redress, it is on the agenda of the 2016-2022 Action Plan to review the need to accede to the CRPD's Optional Protocol (MWFCD, 2016). However, missing redress components currently remains an issue as external university redress is essential in ensuring that the concerns of students with disabilities are heard. Rezaul Islam (2015) surmised that the voices of people with disabilities in Malaysia are often overlooked in decisions concerning them.

Thus, Malaysia can learn from Australia's practice that calls for feedback from all stakeholders (including students with disabilities and their carers) in the 5-yearly review of the 2005 DSE. An official review on the effectiveness of the PwDA can be carried out every 5-7 years by the NCPD in collaboration with the DSW. Such a review practice is in line with the core strategies found in the 2016-2022 Action Plan. Similar to England and Australia, they can commission a research institute or a university to conduct the study. Specific to higher education, the NCPD can work with the MoHE to conduct a review on the impact of the PwDA and the national policy and action plan on the universities so far. Malaysian higher education institutions can also do their part by approaching the Ministry to initiate official government studies.

In terms of monitoring, a reporting framework could be set up by the MoHE, requiring universities to submit information on disability or equality performance indicators, progress, milestones, and plans every 2-3 years. For both review and monitoring. the reports ought to be available on the Ministry's website. This practice is congruent with the first strategy of the 8th Core Strategy found in the 2016-2022 Action Plan to widely distribute research findings. Public information on the review and monitoring systems, methods, conclusions, and recommendations will also encourage more research to be done on disability in higher education. Perren et al. (2012a) concluded external regulatory pressure to be the component that most compels organisations to champion the equality agenda (as compared with internal organisational factors such as staff). The government would be a good external regulator for universities in such matters.

As for redress, it is recommended that a national grievance system for students with disabilities be developed by the NCPD. As a first step, a local quasi-judicial mechanism could be inserted. The Council could set up an independent national body that conciliates the complaints of students with disabilities such as that of the OIA in England and the AHRC, Australia (though the AHRC also applies to the broader community). This independent entity would be tasked with investigating grievances and making recommendations. Nonetheless, introducing court options to the redress system should be the long-term goal. Domestic legislation ought to provide for judicial mechanisms in the event of disability rights violation (UNESCO, 2017b; United Nations, 1993) for the right to education should be justiciable (Singh, 2013).

In the meantime, to safeguard redress opportunity at the institutional level, universities ought to ensure that students with disabilities are aware of the internal complaints mechanism. During orientation, all students - with or without disabilities - should be introduced to the process and procedure (e.g., what happens after a complaint, duration of process, what can be expected). Furthermore, the information should be posted on the institution's website at the disability section. Perren et al. (2012) found that some organisations in their study did in fact adjust their practices and procedures after discrimination disputes were worked out. Thus, instating an effective redress system is essential.

\section{Challenges of the Study}

Document analysis was sometimes challenged by missing disability data and information in the public domain. In the case of Malaysia, data collection was especially difficult as there is a lack of an integrated system and comprehensive data on people and students with disabilities. Different ministries and departments hold various aspects of the disability data with no streamlining mechanism by a main body. 


\section{Further Research}

Besides the sector's policies and practices, there are other elements that influence the participation of students with disabilities in higher education. Examples would be the policies and practices that govern disability at the lower education levels and the major geographical elements (rural vs. urban). Furthermore, certain issues presented in this paper are related to the country's organisation as a whole, not just the higher education sector. For instance, in Malaysia, the lack of a redress system for higher education students with disabilities stems from the general lack of a redress mechanism for people with disabilities (cf., in Australia, the CRPD's Optional Protocol or the AHRC is open to all Australians with disabilities, not just students). Future studies could look into such factors.

Other than that, another key area for further research would be the development of the national redress system in Malaysia. Research is needed in establishing the mechanism of the above-recommended conciliation entity. Some methods that work in England and Australia (the advanced nations) may not be as effective in Malaysia, especially when the workings involve issues like disability awareness. Though inadequate disability awareness plagues all three countries, each nation is at a different point of the awareness scale.

For instance, in England and Australia, the concern for 'image' among its public is a major driver for an establishment's compliance to disability legislation (Perren et al., 2012a; interview respondent, Australian university). At present, this factor is not applicable in Malaysia. For image to be an adequate driver, disability awareness and priority in society would have to be at a level higher than that which currently prevails in the country.

In relation to conciliation, for example in England, the OIA may hold no legal powers to impose penalties. The universities, however, would most likely heed the Office's recommendations or risk being highlighted to the Office's Board and in its annual report (OIA, 2017b). Again, this approach requires a certain level of disability awareness among the public to be effective. Hence, the said Malaysian entity may not be able to outright adopt this practice. Adaptation has to be considered. Thus, further research is necessary in developing the workings of this entity to operate effectively within the Malaysian context.

\section{Conclusion}

Undoubtedly, Malaysia does have legislation, funding, and governance policies and practices for disability in higher education. However, these policies and practices have to be further developed. Reflecting upon Malaysia's mechanisms against those of England and Australia to make recommendations did not imply that the systems of the advanced nations are infallible. It did, however, signal that progress in certain disability aspects in Malaysia is due. This study was carried out to give overall direction and to identify the next step of incremental growth suited to the local context.

Developing supporting guidelines to legislation, which in future could also hold redress guidance, will aid all involved with disability in higher education to better understand their rights and roles. Arranging for essential data to be in the public domain, especially online, is key to not only that understanding but to greater research quality. Ease of access to information should also be considered by universities. Planning for visibility of disability information in their public spaces will draw in more students with disabilities. Essentially, this research is largely aimed at improving the participation of these students, a cause very much in line with the education agenda of Malaysia's 2016-2022 Action Plan. 


\section{Notes}

${ }^{1}$ This paper covers the policies and practices of England, not the entire United Kingdom. The Legislation section is the only part that covers Britain because the Equality Act 2010 applies to the whole of Britain.

${ }^{2}$ HEFCE, which stopped operating on 1 April 2018, was replaced by 1) UK Research and Innovation, and 2) Office for Students. Disability funding falls under the Office for Students. HEFCE is quoted throughout this paper because this research was conducted in 2016/2017.

${ }^{3}$ The Optional Protocol institutes a redress mechanism for when rights have been infringed at the member states of the CRPD (OHCHR, 2017a). To this end, the Committee on the Rights of Persons with Disabilities is charged with two agenda: 1) review individual complaints, and 2) inquire into evidence-substantiated violations of the Convention. Convention participation does not imply automatic membership with the Optional Protocol. For the said redress procedure to take effect, however, the state in question must be a member of the Optional Protocol.

${ }^{4}$ The authors would like to thank Stephen Manson, Ahmad Firdaus Ahmad Shabudin, Morshidi Sirat, and Wan Chang Da for their help in strengthening this manuscript.

\section{References}

Australian Human Rights Commission (AHRC) Act, Australia, No. 125 (1986).

Australian Law Reform Commission. (2017). Aboriginal Customary Laws and Anglo-Australian Law after 1788. Available at http://www.alrc.gov.au/publications/4.\%20Aboriginal\%20 Customary\%20Laws\%20and\%20Anglo-Australian\%20Law\%20After\%201788/australian-lawapplied[Accessed 2 September 2017].

Barnes, C. (2007). Disability activism and the struggle for change: Disability, policy and politics in the UK. Education, Citizenship and Social Justice, 2(3), pp.203-221.

Castles, A. C. (1963). The reception and status of English Law in Australia. Adelaide Law Review, 2(1), pp.1-31.

Centre for Disability Studies and School of Sociology and Social Policy (CDSSSP) (2009). Evaluation of Provision and Support for Disabled Students in Higher Education. Leeds, England: CDSSSP.

Committee on the Rights of Persons with Disabilities. (2009). Guidelines on Treaty-Specific Document to be Submitted by States Parties under Article 35, Paragraph 1, of the Convention on the Rights of Persons with Disabilities. Available at https://digitallibrary.un.org/record/672005[Accessed 2 September 2017].

Committee on the Rights of Persons with Disabilities. (2016). Guidelines on Periodic Reporting to the Committee on the Rights of Persons with Disabilities, Including under the Simplified Reporting Procedures. Available at http://www.ohchr.org/EN/HRBodies/CRPD/Pages/ Simplifiedreportingprocedure.aspx[Accessed 2 September 2017].

Commonwealth of Australia. (2011). 2010-2020 National Disability Strategy: An Initiative of the Council of Australian Governments. Canberra: Commonwealth of Australia.

Commonwealth of Australia. (2012). Higher Education Support Act 2003: Other Grants Guidelines (Education) 2012. Available at https://www.legislation.gov.au/Details/F2012L00281[Accessed 2 September 2017].

Department of Education and Training, Australia (DET). (2014). Selected Higher Education Statistics - 2013 Student Data. Available at https://www.education.gov.au/selected-higher-educationstatistics-2013-student-data[Accessed 24 September 2017].

Department of Education and Training, Australia (DET). (2015a). Evaluation of the Disability Support Program-Executive Summary. Zurich: KPMG.

Department of Education and Training, Australia (DET). (2015b). Selected Higher Education Statistics - 2014 Student Data. Available at https://www.education.gov.au/selected-higher-educationstatistics-2014-student-data[Accessed 24 September 2017].

Department of Education and Training, Australia (DET). (2016a). Disability Standards for Education 2005. Available at https://www.education.gov.au/disability-standards-education-2005[Accessed 11 September 2017]. 
Department of Education and Training, Australia (DET). (2016b). Selected Higher Education Statistics - 2015 Student Data. Available at https://www.education.gov.au/selected-higher-educationstatistics-2015-student-data[Accessed 24 September 2017].

Department of Human Services, Australia (DHS). (2017). Pensioner Education Supplement. Available at https://www.humanservices.gov.au/individuals/services/centrelink/pensioner-educationsupplement[Accessed 13 September 2017].

Department of Social Services (DSS). (2015). Progress Report to the Council of Australian Governments 2014. Canberra: DSS.

Department of Social Welfare, Malaysia (DSW). (2017a). List of Facilities and Privileges for Persons with Disabilities. Available at http://www.jkm.gov.my/jkm/index.php?r=portal/left\&id=OHFw b3Rmbk1KTUJLbmFiSzkyTElkUT09[Accessed 11 September 2017].

Department of Social Welfare, Malaysia (DSW). (2017b). Registration of Persons with Disabilities. Available at http://www.jkm.gov.my/jkm/index.php?r=portal/left\&id=UnN2U3dtUHhacVN4a HNPbUIPayt2QT09[Accessed 7 September 2017].

Disability Discrimination Act (DDA), Australia, No. 135 (1992).

Disability Rights UK. (2017). Making a Complaint. Available at https://www.disabilityrightsuk.org/ making-complaint[Accessed 23 September 2017].

Disability Standards for Education (plus Guidance Notes; DSE), Australia (2005).

Equality Act, Britain (2010).

Equal Opportunity Act, South Australia, 1.8.2017 (1984).

Equal Opportunity Commission (EOC). (2013). Equal Opportunity and You: Information booklet. South Australia: EOC.

Equality and Human Rights Commission, Britain (EHRC). (2012). Publishing Equality Information: Commitment, Engagement and Transparency. Manchester: EHRC.

Equality and Human Rights Commission, Britain (EHRC). (2013). Assessment of the Publication of Equality Objectives by English Public Authorities. Manchester: EHRC.

Equality and Human Rights Commission, Britain (EHRC). (2014a). Equality Act 2010 Technical Guidance on Further and Higher Education. Manchester: EHRC.

Equality and Human Rights Commission, Britain (EHRC). (2014b). What Equality Law Means for You as an Education Provider - Further and Higher education. Manchester: EHRC.

Equality and Human Rights Commission, Britain (EHRC). (2014c) What Equality Law Means for You as a Student in Further or Higher Education. Manchester: EHRC.

Equality and Human Rights Commission, Britain (EHRC). (2015). Is Britain Fairer? The State of Equality and Human Rights 2015. Manchester: EHRC.

Equality and Human Rights Commission, Britain (EHRC). (2016). Monitoring and Enforcement. Available at https://www.equalityhumanrights.com/en/advice-and-guidance/monitoring-andenforcement[Accessed 21 September 2017].

Equality and Human Rights Commission, Britain (EHRC). (2017a). Being Disabled in Britain: A Journey Less Equal. Manchester: EHRC.

Equality and Human Rights Commission, Britain (EHRC). (2017b). Our Powers. Available at https:// www.equalityhumanrights.com/en/our-legal-action/our-powers[Accessed 21 September 2017].

Equality Challenge Unit, United Kingdom (ECU). (2014). Equality in Higher Education: Statistical Report 2014. Available at http://www.ecu.ac.uk/publications/equality-higher-education-statisticalreport-2014/[Accessed 2 September 2017].

Equality Challenge Unit, United Kingdom (ECU). (2015). Equality in Higher Education: Statistical Report 2015. Available at http://www.ecu.ac.uk/publications/equality-higher-education-statisticalreport-2015/[Accessed 2 September 2017]. 
Equality Challenge Unit, United Kingdom (ECU). (2016). Equality in Higher Education: Statistical Report 2016. Available at http://www.ecu.ac.uk/publications/equality-in-higher-educationstatistical-report-2016/[Accessed 2 September 2017].

Government of the United Kingdom (GUK). (2017a). Help if You're a Student with a Learning Difficulty, Health Problem or Disability: Eligibility. Available at https://www.gov.uk/disabled-studentsallowances-dsas/eligibility[Accessed 13 September 2017].

Government of the United Kingdom (GUK). (2017b). NHS Bursaries: Extra Financial Help. Available at https://www.gov.uk/nhs-bursaries/further-information[Accessed 13 September 2017].

Grech, S. (2011). Recolonising debates or perpetuated coloniality? Decentring the spaces of disability, development and community in the global South. International Journal of Inclusive Education, 15(1), pp.87-100.

Higher Education Funding Council for England (HEFCE). (2012). HEFCE Equality \& Diversity Scheme 2012-2014. Bristol: HEFCE.

Higher Education Funding Council for England (HEFCE). (2017). Guide to Funding 2017-18 How HEFCE allocates its funds. Bristol: HEFCE.

Higher Education Statistics Agency (HESA). (2017). Students, Qualifiers and Staff Data Tables: Students by Disability. Available at https://www.hesa.ac.uk/data-and-analysis/keytables?year=All\&by=581[Accessed 2 June 2018].

House of Lords, United Kingdom. (2016). The Equality Act 2010: The Impact on Disabled People. London: House of Lords, UK.

Kamarulzaman , K. (2007). Adult learning for people with disabilities in Malaysia: Provisions and services. The Journal of Human Resource and Adult Learning, 3(2), pp.50-64.

Koshy, P. (2016). Student Equity Performance in Australian Higher Education: 2008 to 2015. Perth: National Centre for Student Equity in Higher Education (NCSEHE), Curtin University.

Lee, L. W., \& Low, H. M. (2014). The evolution of special education in Malaysia. British Journal of Special Education, 41(1), pp.42-58.

Meekosha, H. (2011). Decolonising disability: Thinking and acting globally. Disability \& Society, 26(6), pp.667-682.

Ministry of Education, Malaysia (MoE). (2013). Malaysia Education Blueprint 2013-2025 (preschool to post-secondary education). Putrajaya: MoE.

Ministry of Education, Malaysia (MoE). (2014). Graduate Tracer Study 2013. Putrajaya: MoE.

Ministry of Education, Malaysia (MoE). (2015). Malaysia Education Blueprint 2015-2025 (higher education). Putrajaya: MoE.

Ministry of Higher Education, Malaysia (MoHE). (2013). National Education Statistic: Higher Education Sector 2012. Putrajaya: MoHE.

Ministry of Higher Education, Malaysia (MoHE). (2015a). Graduate Tracer Study 2014. Putrajaya: MoHE.

Ministry of Higher Education, Malaysia (MoHE). (2015b). National Education Statistic: Higher Education Sector 2014. Putrajaya: MoHE.

Ministry of Higher Education, Malaysia (MoHE). (2016a). Graduate Tracer Study 2015. Putrajaya: MoHE.

Ministry of Higher Education, Malaysia (MoHE). (2016b). National Education Statistic: Higher Education Sector 2015. Putrajaya: MoHE.

Ministry of Women, Family and Community Development, Malaysia (MWFCD). (2007). Policy for Persons with Disabilities. Putrajaya: MWFCD.

Ministry of Women, Family and Community Development, Malaysia (MWFCD). (2016). People with Disabilities Action Plan 2016-2022. Putrajaya: MWFCD. 
National Centre for Student Equity in Higher Education (NCSEHE). (2017a). NCSEHE Focus: Successful Outcomes for Students with Disability in Australian Higher Education. Perth: Curtin University.

National Centre for Student Equity in Higher Education (NCSEHE). (2017b). Research Reports and Discussion Papers. Available at https://www.ncsehe.edu.au/research/research-reports/ [Accessed 24 September 2017].

Office of the Independent Adjudicator (OIA). (2017a). About us: Background. Available at http:// www.oiahe.org.uk/about-us.aspx[Accessed 23 September 2017].

Office of the Independent Adjudicator (OIA). (2017b). Using the Scheme: What Happens After the Final Complaint Outcome is Issued? Available at http://www.oiahe.org.uk/about-us/using-thescheme.aspx[Accessed 26 September 2017].

Office of the United Nations High Commissioner for Human Rights (OHCHR). (2017a). Committee on the Rights of Persons with Disabilities: Questions and Answers. Available at http://www. ohchr.org/EN/HRBodies/CRPD/Pages/QuestionsAnswers.aspx[Accessed 23 September 2017].

Office of the United Nations High Commissioner for Human Rights (OHCHR). (2017b). Human Rights Treaty Bodies - Individual Communications. Available at http://www.ohchr.org/EN/ HRBodies/TBPetitions/Pages/IndividualCommunications.aspx\#procedureCRPD[Accessed 23 September 2017].

Organization for Economic Co-operation and Development (OECD). (2011). Inclusion of Students with Disabilities in Tertiary Education and Employment. Paris: OECD.

Perren, K., Roberts, S., Stafford, B., \& Hirsch, D. (2012a). Evaluation of the Implementation of the Equality Act 2010: Report 1 - Organisational Approaches to Equality. London: Government Equalities Office.

Perren, K., Roberts, S., Stafford, B., \& Hirsch, D. (2012b). Evaluation of the Implementation of the Equality Act 2010: Report 2 - Awareness and Impact of the Equality Act. London: Government Equalities Office.

Perren, K., Roberts, S., Stafford, B., Hirsch, D, \& Padley, M. (2012). Evaluation of the Implementation of the Equality Act 2010: Report 3 - Disputes and challenges. London: Government Equalities Office.

Persons with Disabilities Act (PwDA), Laws of Malaysia, Act 685 (2008).

Rezaul Islam, M. (2015). Rights of the people with disabilities and social exclusion in Malaysia. International Journal of Social Science and Humanity, 5(2), pp.171-177.

Shaikh Mohamed, N., \& Supramaniam, S. (2016). An Overview of Malaysian legal System and Research.. Available at http://www.nyulawglobal.org/globalex/Malaysia1.html[Accessed 13 September 2017].

Singh, K. (2013). Report of the Special Rapporteur on the Right to Education. Justiciability of the Right to Education. New York: United Nations.

Singh, H. (2014). Reporting to UN on Current Status of PWD towards an Inclusive Malaysian Society Post UNCRPD Ratification. Paper presented at the BAKTI-MIND Conference VI, Kuala Lumpur, Malaysia, 22-27 August 2014.

Sinnasamy, M. (2010). The Needs of Disabled Persons in Malaysia are Still Seen Largely as a Welfare Function. Available at https://www.dnis.org/interview.php?issue_id=6\&volume_ id=7\&interview_id=150[Accessed 13 September 2017].

United Nations. (1993). The Standard Rules on the Equalization of Opportunities for Persons with Disabilities. Available at http://www.un.org/esa/socdev/enable/dissre00.htm[Accessed 26 September 2017].

United Nations. (2017a). Convention on the Rights of Persons with Disabilities. Available at https:// treaties.un.org/Pages/ViewDetails.aspx?src=TREATY\&mtdsg_no=IV-15\&chapter=4\&clang=_ en[Accessed 11 September 2017]. 
United Nations. (2017b). Goal 4 Targets. Available at http://www.undp.org/content/undp/en/home/ sustainable-development-goals/goal-4-quality-education/targets/[Accessed 6 September 2017].

United Nations. (2017c). Optional Protocol to the Convention on the Rights of Persons with Disabilities. Available at https://treaties.un.org/Pages/ViewDetails.aspx?src=TREATY\&mtdsg_no=IV-15a\&chapter=4\&clang=_en[Accessed 11 September 2017].

United Nations Children's Fund (UNICEF), Malaysia. (2014). Children with Disabilities in Malaysia: Mapping the Policies, Programmes, Interventions and Stakeholders. New York: UNICEF.

United Nations Economic and Social Commission for Asia and the Pacific (UNESCAP). (2012). Incheon Strategy to "Make the Right Real" for Persons with Disabilities in Asia and the Pacific. Bangkok: UNESCAP.

United Nations Educational, Scientific and Cultural Organization (UNESCO). (2014). The Right to Education: Law and Policy Review Guidelines. Paris: UNESCO.

United Nations Educational, Scientific and Cultural Organization (UNESCO). (2016). Education 2030. Incheon Declaration and Framework for Action. Paris: UNESCO.

United Nations Educational, Scientific and Cultural Organization (UNESCO). (2017a). A Guide for Ensuring Inclusion and Equity in Education. Paris: UNESCO.

United Nations Educational, Scientific and Cultural Organization (UNESCO). (2017b). Right to Education - Support and Cooperation. Available at http://en.unesco.org/themes/right-toeducation/support-cooperation[Accessed 26 September 2017].

University of Canberra. (2014). Disability Standards for Education: A Practical Guide for Individuals, Families and Communities. Available at http://resource.dse.theeducationinstitute.edu.au/ [Accessed 11 September 2017].

Urbis. (2015). 2015 Review of the Disability Standards for Education 2005: Final Report. Sydney: Urbis

World Health Organization. (2013). 10 Facts on Disability. Available at http://www.who.int/features/ factfiles/disability/en/\#[Accessed 6 September 2017]. 
